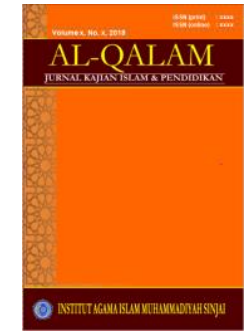

AL-QALAM

Jurnal Kajian Islam \& Pendidikan

Volume 7, No. 1, 2015

ISSN (print) : 1858-4152

ISSN (online) : 2715-5684

Homepage : http://journal.al-qalam.iaims.ac.id

\title{
PERKEMBANGAN PENDIDIKAN ISLAM: MERESPON TANTANGAN
}

\section{GLOBALISASI}

\author{
Oleh: Burhanuddin*
}

\begin{abstract}
Abstrak
Dalam konteks ke-Indonesiaan, banyak hal perlu dicermati dalam kerangka terhadap Pendidikan Islam dan Globalisasi. Karena itu, secara konsesional umat Islam Indonesia bertanggung jawab dan memiliki kontribusi besar atas perkembangan dan kemajuan Indonesia dalam semua aspek pembangunan, tidak terkecuali dalam bidang pendidikan. Untuk menguraikan pembahasan tentang perkembangan pendidikan Islam dalam merespon tantangan globalisasi, maka pembahasan di arahkan melalui tiga rumusan masalah yaitu: 1) Bagaimana hakikat pendidikan Islam?; 2) Globalisasi dan Dampaknya Dalam Dunia Pendidikan?; dan 3) Tantangan dan Peluang Pendidikan Islam? Hasi pembahasan menunjukkan diperlukan adanya perombakan pada kebijakan yang menyangkut masalah pendidikan dengan menelurkan kebijakan-kebijakan yang berpihak pada kaum miskin, komersialisasi pendidikan mutlak harus dihentikan karena hanya memunculkan sekelompok orang yang menggunakan pendidikan sebagai alat untuk mendapatkan keuntungan. Upaya memformulasikan kembali teori dan praktek pendidikan Islam sehingga dapat dilakukan kontekstualisasi arus global dengan menghilangkan batas pendidikan Islam yang dikotomik menuju pendidikan yang integralistik.
\end{abstract}

Kata Kunci: Islam, Pendidikan, Globalisasi, Kebijakan, Kontektualisasi

\section{PENDAHULUAN}

Globalisasi merupakan fenomena yang tak terhindarkan pada penghujung dasawarsa pertama abad ke-21 ditandai dengan kemajuan teknologi komunikasi informasi dan transportasi telah menghasilkan perubahan dalam kebudayaan manusia. Umat Islam sebagai bagian dari komunitas dunia, cenderung kurang mampu mengikuti perkembangan zaman. Apalagi jika ingin mengungguli bangsa lain dalam penguasaan ilmu pengetahuan dan teknologi untuk mengarahkan perubahan kehidupan ke arah yang lebih baik tentu saja semakin sangat rumit. Padahal Islam sangat memperhatikan upaya menciptakan generasi qur'ani (pandangan dan perilaku berbasis nilai qur'an), pribadi berkarakter, dan berkualitas. Generasi yang diharapkan tampil dengan kekuatan iman dan taqwa, memiliki kertampilan, menguasai ilmu pengatahuan dan teknologi, menuju pembumian nilai Islam secara kaffah, ${ }^{1}$ cita ideal ini perlu diwujudkan sebagai upaya memenuhi tugas risalah, menyemai suburnya iman, menbagun kekuatan budaya Islam dengan mengamalkan Islam sebagai rahmatan lil

\footnotetext{
* Dosen DPK STAI Muhammadiyah Sinjai

${ }^{1}$ Lihat.QS. 4:9; 2:208; 3:104, 110
} 


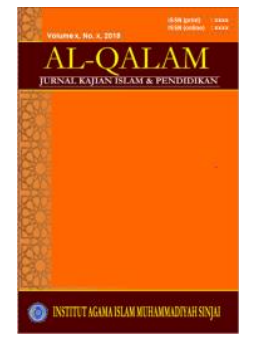

AL-QALAM

Jurnal Kajian Islam \& Pendidikan

Volume 7, No. 1, 2015

ISSN (print) : 1858-4152

ISSN (online) : 2715-5684

Homepage : http://journal.al-qalam.iaims.ac.id

'alamain. ${ }^{2}$ Visi keunggulan dan daya aing umat, sebagai umat terbaik, ${ }^{3}$ umat tengah/adil sebagai saksi sejarah yang mendapat petunjuk.

Dalam perspektif global ada beberapa faktor yang disoroti oleh Djamali, sebagai fonomena kemuduran umat, yaitu: kemunduran bidang agama, akhlak, keterbelakangan ilmu pengatahuan, dan teknologi, keterbelakangan ekonomi, sosial, kesehatan, politik, manajemen, dan bidang pendidikan ${ }^{4}$ secara global di dunia Islam, faktor-faktor tersebut yang menperlemah peran umat Islam dalam memaksimalkan kemampuan atau daya saing dalam pecaturan dunia global. Umat Islam nampaknya masih kurang memiliki daya saing global karena keterbelakangan sistemik yang belum bisa dieliminir melalui upaya melejitkan potensi dan kemampuan kompetitif serta kooperatif umat Islam. Sudah saatnya umat Islam menetapkan strategi mewujudkan kemajuan dan kedamaian dalam tatanan dunia baru Islam tidak hanya melalui peran politik, tetapi justru melalui pemantapan peran kulturalisasi Islam secara komperehensif.

Semua persoalan yang memperlemah kondisi umat harus di atas melalui upaya strategis memperkuat sumberdaya umat Islam, baik sumberdaya manusia, alam, sosial, IPTEK, maupun modal/keuangan. Salah satu upaya strategis kearah peningkatan kualitas umat adalah dengan membenahi sistem pendidikan yang secara langsung berkaitan dengan pengembangan sumberdaya manusia berkualitas sesuai keperluan lokal, Nasional, regional, dan global. Ketersediaan sumberdaya manusia (human resources) atau SDM unggul yang mampu menjawab persaingan dan bekerja sama mewujudkan kebaikan untuk semua, ${ }^{5}$ harus menjadi visi perjuangan umat dalam semua level dan segmen kehidupan.

Dalam konteks ke-Indonesiaan, banyak hal perlu dicermati dalam kerangka terhadap Pendidikan Islam dan Globalisasi. Islam di Indonesia adalah fakta mayoritas umat. ${ }^{6}$ Karena itu, secara konsesional umat Islam Indonesia bertanggung jawab dan memiliki kontribusi besar atas perkembangan dan kemajuan Indonesia dalam semua aspek pembangunan, tak terkecuali dalam bidang pendidikan.

Untuk menguraikan pembahasan tentang perkembangan pendidikan Islam dalam merespon tantangan globalisasi, maka pembahasan di arahkan melalui tiga rumusan masalah yaitu: 1) Bagaimana hakikat pendidikan Islam?; 2) Globalisasi dan Dampaknya Dalam Dunia Pendidikan?; dan 3) Tantangan dan Peluang Pendidikan Islam?

\section{PEMBAHASAN}

\section{A. Hakikat Pendidikan Islam}

Pendidikan adalah fenomena kultural/budaya suatu masyarakat. Perkembangan budaya merupakan produk system pendidikan yang dijalankan oleh suatu masyarakat.

\footnotetext{
${ }^{2}$ QS. 21:107

${ }^{3}$ QS. 3:110; QS. 2:143

${ }^{4}$ Fadhil Al-Djamali, Menerebas Krisis Pendidikan Dunia Islam, (Jakarta: PT. Golden Terayon Press, 1993), h. 58-59 h.114

${ }^{5}$ Semangat kompetitif, Fastabiqul Khairat, QS. 2:147; QS.5:48, sekaligus membangun kerjasama untuk kebaikan (ta'awun) (QS.6:2)

${ }^{6}$ Penduduk beragama Islam di Indonesia lebih 207 juta $(88,20)$ dari 240 -an juta jumlah penduduk negeri ini. Begitupun secara kualitatif umat Islam dalam berbagai aspek kehidupan masih lemah kondisinya.
} 


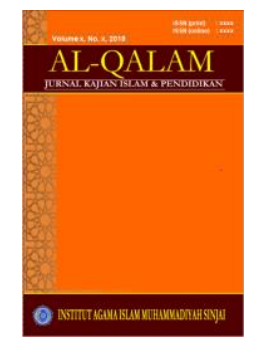

AL-QALAM

Jurnal Kajian Islam \& Pendidikan

Volume 7, No. 1, 2015

ISSN (print) : 1858-4152

ISSN (online) : 2715-5684

Homepage : http://journal.al-qalam.iaims.ac.id

Sedangkan pengembangan budaya adalah khas manusia. Tak pelak, manusia menjadi satusatunya makhluk Allah yang berbudaya dan mampu mengembangkan kebudayaannya. Sebagai fenomena kebudayaan, maka pendidikan menjadi faktor yag menjamin pembinaan potensi secara maksimal guna mencapai kedewasaaan individu dan memelihara eksistensi serta perkembangan suatu masyarakat dalam mengisi kehidupan dengan pengabdian dan kekhalifahannya secara berkualitas/unggul sebagai insan shaleh di muka bumi. ${ }^{7}$

Langgulung, ${ }^{8}$ menyatakan bahwa pendidikan adalah suatu proses yang mempunyai tujuan yang biasanya diusahakan untuk menciptakan pola-pola tingkah laku tertentu pada kanak-kanak atau orang yang sedang dididik. Setiap suasana pendidikan mengandung tujuantujuan, maklumat-maklumat berkenaan dengan pengalaman-penglaman yang dinyatakan sebagai materi, dan metode yang sesuai untuk mempersembahkan materi itu secara berkesan kepada anak.

Sedangkan tujuan pendidikan Islam ditegaskan bahwa: "The aim of education in Islam is to produce a good man" yang berarti bahwa tujuan pendidikan Islam adalah menghasilkan pribadi manusia yang baik. Adapun yang baik itu adalah berkenaan dengan adab, berkenaan esensi budi dalam percapaian kualitas kebaikan dimensi spiritual dan material manusia. ${ }^{9}$

Pendidikan membantu dalam menyenpurnakan kepribadian seseorang atau kelompok untuk melakukan tugas-tugas secara efisien. ${ }^{10}$ Karena itu pendidikan Islam selain sebagai proses pembinaan fitrah/potensi anak sekaligus merupakan transformasi kebudayaan sehingga eksistensi dan pengembangan hidup umat Islam berlangsung berkelanjutan. Tujuan yang ditata Islam dalam pendidikan adalah membuat kepatuhan manusia, dan menghambakan diri sepenuhnya pada Allah. Pendidikan adalah proses pemenuhan keyakinan dan cita-cita pendidikan Islam adalah keagamaan. Pendidikan Islam membuat kesadaran manusia sebagai kenyataan jiwa mempengaruhi kegiatan dan kehidupan tidak sempurna dan hanya melalui pendidikan maka bimbingan jiwa mencapai keunggulannya. ${ }^{11}$

Secara sistemik, sistem pendidikan adalah keseluruhan komponon yang terpadu, saling berhubungan dan berfungsi dalam mencapai tujuan. Sistem pendidikan Islam dibentuk dan diteteskan dari filosofi pendidikan Islam yang mempertayakan dan menjawab persoalan hakikat manusia, tujuan penciptaan manusia, hakikat pengetahuan (epistemologi), dan hakikat nilai (aksiologi). Secara filosofi, manusia/anak adalah makluk theomorfik, (manusia berasal dari tuhan kembali kepada tuhan) yang diberi amanah sebagai khalifah (pemimpin/wakil, penguasa), dan abdun (hamba), ${ }^{12}$ dalam kerangka misi menemukan dan mengamalkan sunatullah untuk keselamatan dan kemakmuran kehidupan umat manusia di

${ }^{7}$ Lihat Al-Baqarah ayat 249

8 Hasan Langgulung, Manusia dan Pendidikan; Suatu Analisa Psikologi, Filsafat dan Pendidikan, (Jakarta: Pustaka Al-Husna, 1989), h. 22.

9 Lihat Syed Naquib Al-Attas, Aims and Objective of Islamic Edication, (Jeddah: Hodder and Stoughton King Abdul Aziz University, 1979), h.1

${ }^{10}$ Syed Naquib Al-Attas dalam pendahuluan Syed Naquib Al-Attas, h. ix. 2003), h. 42

11 Zafar Alam, Islamic Education Theory \& Practive, (New Delhi: Adam Publishers \& Distributors,

12 QS. Al-An'am ayat 165, dan QS. 51:56. 


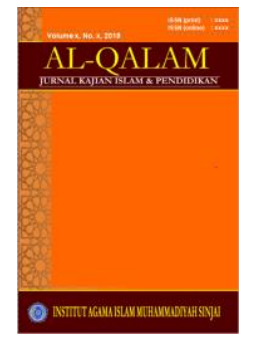

\section{AL-QALAM}

Jurnal Kajian Islam \& Pendidikan

Volume 7, No. 1, 2015

ISSN (print) : 1858-4152

ISSN (online) : 2715-5684

Homepage : http://journal.al-qalam.iaims.ac.id

muka bumi. Dengan memantapkan perpaduan filosofi dan sistem pendidikan Islam sebagaimana mestinya tentu saja memastikan keutuhan idiologi pendidikan Islam yang mengilhami praktik pendidikan yang ideal.

Dengan begitu, sistem pendidikan Islam merupakan upaya mewujudkan sistem pembinaan potensi individu dan umat bagi Islamisasi dalam artian penerimaan dan pelaksanaan secara sadar kultur Islam yang ideal oleh orang-orang yang bukan muslim dan orang-orang yang hanya mengaku muslim. ${ }^{13}$ kehidupan dalam segala aspeknya. Itu artinya, dasar pendidikan Islam adalah sunattullah (Wahyu dan hukum alam/sosial empiris) yang menegaskan tauhid sebagai nilai tertingi dari puncak kebenaran realistas. ${ }^{14}$ Sehinga pengingkaran atas realitas Maha pencipta (Al-Khaliq) dan realistis yang diciptakan (Makhluk) menjadikan seseorang musrik.

Tegasnya tujuan pendidikan Islam berfokus kepada perwujudan sunattullah dalam kehidupan peribadi (muslim sejati) dengan terbinanya seluruh potensi/fitrah anak menjadi pribadi muslim dan masyarakat Islami seutuhnya melalui pendekatan ta'lim tilawah dan tazkiyah, ${ }^{15}$ yang memunculkan berbagai metode, media, dan alat pendidikan dengan materi/nilai sumber dari penafsiran terhadap hukum alam/sosial. bagi Al-Attas, ${ }^{16} \mathrm{Al}-$ Tarbiyah, dan Al-Ta'lim, maka al-ta'dib merupakan istilah yang juga digunakan dalam pendidikan Islam, karena misi utama Rasulullah adalah membaguskan akhlak/adab individu dan masyarakat sebagai diungkap dalam salah satu hadis: "Addabany Rabbi, Fa ahsani Ta'diiby, Tuhanku yang mendidikku dan membaguskan akhlakku".

Sejatinya, sistem pendidikan Islam adalah sistem yag mengacu kepada pemahaman adanya format pendidikan yang berasaskan Islam, dan atau bernuansa Islami untuk mewujudkan nilai-nilai Islam dalam program, proses, dan aktifitas pembelajaran. Dalam wujudnya, ada berbagai lembaga pendidikan Islam, yaitu Madrasah, Pesantren dan Sekolah Islam atau sekolah yang di kelola organisasi/yayasan Islam yang diyakini dalam pengembangannya untuk mewujudkan tujuan pendidikan Islam, melalui materi/isi, proses, kegiatan, dan metode pendidikan yang Islami dalam rangka meraih kualitas/keunggulan pribadi muslim sejati dan masyarakat Islam terbaik/unggul. ${ }^{17}$

Pentingnya pendidikan tidak hanya bagi pencapaian tujuannya, tetapi merupakan bagian integral sebagai suatu agama. Istilah pendidikan, "Al-Ta'lim" dan Al-Tarbiyah" dapat diinterpretasikan dalam kenyataannya sebagai inti dari kehidupan religius, mengarahkan manusia melalui Al-Ta'lim dari proses transformasi pengetahuan, sama halnya dengan AlTarbiyah atau pelatihan terhadap jiwa untuk mencapai derajat kesempurnaan lebih besar sampai pada perjumpaan dengan Allah ${ }^{18}$ melaui proses Al-Ta'lim, Rasulullah mengajarkan membaca Al-Qur'an kepada kaum muslimin tidak sekedar membaca saja, melainkan membaca dengan perenungan berisikan pemahaman, pengertian, tanggung jawab dan

${ }^{13}$ Lihat S.Wakar Ahmed Husaini, Sistem Pembinaan Masyarakat Islam, (Bandung: Pustaka, 1983), h.

${ }^{14}$ Lihat QS. An Nisa' ayat 48 dan 116

${ }^{15}$ Al Baqarah ayat 128, dan 151

${ }^{16}$ Syed Naquib Al-Attas, op.cit. h. 2

17 Ibid, h. 4

${ }^{18}$ QS. 3:104 dan 110 


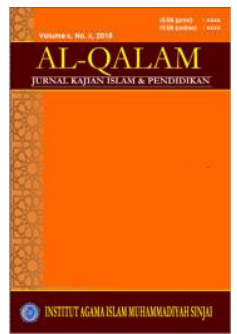

AL-QALAM

Jurnal Kajian Islam \& Pendidikan

Volume 7, No. 1, 2015

ISSN (print) : 1858-4152

ISSN (online) : 2715-5684

Homepage : http://journal.al-qalam.iaims.ac.id

penanaman amanah. Dari terampil membaca, Rasul membawa umat kepada Al-Tazkiyah (pengsucian jiwa) yaitu membersihkan jiwa manusia menjadi muslim sejati/taqwa. ${ }^{19}$ Menurut Al-Baqi, Al-Tarbiyah dengan berbagai kata yang serumpun dengannya disebutkan sebanyak lebih dari 872 kali. $^{20}$ Tarbiyah sebagai istilah bagi pendidikan Islam ialah proses persiapan dan pengasuhan pada fase pertama pertumbuhan manusia atau masa kanak kanak masa pertumbuhan dan perkembangan anak menjadi tanggung jawab orangtua dengan mendidik penuh kasih sayang.

Peran para pendidik dalam mendidik anak tentu saja harus diarahkan untuk mengembangkan potensi/talenta anak secara maksimal dan menyiapkan lingkungan yang kondusif bagi pembelajaran sehingga tercapai kedewasaan yang maksimal (intelektualitas, moralitas, estetik, spiritualitas) sebagaimana pribadi muslim sejati/insan saleh. Tegasnya, pribadi yang diinginkan sistem pendidikan sekolah Islam adalah yang memiliki kecerdasan intelek, emosi dan spiritual secara terpadu. Suatu perpaduan berpikir Islami (aqliyah Islamiyah) cara berpikir dengan landasan Islam dan menjadikan Islam sebagai satu satunya standard pemikiran, dan dengan sikap Islami (nafsiyah Islamiyah) sikap jiwa dan kecenderungan berpedoman kepada Islam dalam standar pemuasan semua kebutuhan manusia.

Kajian sumber ilmu pengetahuan adalah ketundukan kepada Allah, penjelajahan atas alam semesta,dan kedirian manusia sebagai ciptaan Allah dalam kontek ini ada tiga pendekatan yang dapat dilakukan dalam penyusunan kurikulum pendidikan Islam, yaitu : pendekatan agama (religious approach), yaitu menanamkan ajaran ajaran agma agar materi pelajaran agama yang akan disampaikan kepada siswa harus sesuai dengan daya dan perkembangan kemampuan menerima mereka,dan diberikan secara bertahap,karena bidang pengetahuan agamasangat luas. Dalam Penyusunan kurikulum perlu diperhatikan tiga aspek, yaitu kesinambungan (kontinuiti), berurutan (sequance) dan aspek keterpaduan (integration). ${ }^{21}$

Pembelajaran dalam pendidikan Islam harus menyediakan lingkungan yang memudahkan anak-anak memahami dimensi ketuhanan, alam semesta dan dirinya sehingga anak mampu mengkonstruk pengetahuanya. Berpijak pada kerangka konseptual sebagaimana diungkap di atas berarti sistem pendidikan Islam bermakna sebagai suatu keterpaduan komponen pendidikan Islam yang mengarahkan implementasi proses pembinaan fitrah manusia melalui transformasi kebudayaan sebagaimana yang ada dalam struktur program kurikulum untuk mencapai tujuan pendidikan Islam baik berupa madrasah sekolah agama maupun pesantren yang turut memberikan kontribusi signifikan dalam spektrum upaya umat menjalankan misi kehidupan Islam sesuai tuntunan dan tuntutan ajaran Islam.

Dalam perspektif individu, fungsi pendidikan Islam adalah sebagai karakterisasi mengarahkan pembinaan potensi anak menuju terbentuknya pribadi muslim seutuhnya

${ }^{19}$ QS. Al-Baqarah ayat 151 Al-Tarbiyah diungkapkan pada dua tempat dalam Al-Qur'an; QS. Al-Isra' ayat 24, dan QS. As-Syu'ara ayat 18

20 Muhammad Fu'ad Al-Baqi, Mu'jam Al-Mufahras li-Al Fazh Al-Qur'an Al-Karim, Indonesia; Maktabah Dahlan, tt., h. 362.

${ }^{21}$ Syed Ali Ashraf, New Horizon in Muslim Education. (Jakarta; Pustaka Mantiq, 1989), h. 1 


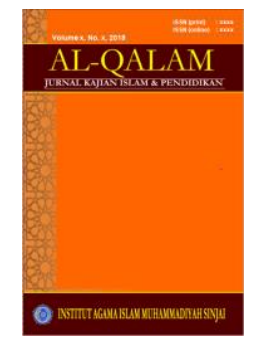

\section{AL-QALAM}

Jurnal Kajian Islam \& Pendidikan

Volume 7, No. 1, 2015

ISSN (print) : 1858-4152

ISSN (online) : 2715-5684

Homepage : http://journal.al-qalam.iaims.ac.id

bahagia di dunia dan di akhirat. Suatu kepribadian yang menjaga keseimbangan hubungan dengan Allah dan hubungan sesama manusia (QS.3:112) dalam perspektif masyarakat, fungsi pendidikan Islam sebagai sosialisasi terbentuknya masyarakat Islam adalah ummat wasatan (umat tengah) (QS.2:143), umat terbaik atau khairah ummah (QS.3:110) dan ummat yang utuh (ummatan wahidah).

Fadil Al-Djamali ${ }^{22}$ mengemukakan pendapat bahwa pada intinya pendidikan Islam memiliki dua sifat fungsi yaitu menunjukan, dan fungsi menangkal. Dijelaskan oleh AlDjamali, bahwa fungsi pendidkan Islam dalam menunjukan, yaitu :

\section{1). Hidayah kepada iman}

Cara terbaik mendidik anak adalah yang mengandung nilai hidayah. Jadi pendidikan merupakan pergaulan yang mengandung rasa kemanusiaan terhadap anak dan mengarahkan kepada kebaikan serta cinta kasih dengan menyediakan suasana bagi perkembangan bakat anak secara maksimal dan lurus. Jadi pendidkan adalah perantaraan ,dalam menumbuhkembangkan fitrah anak dalam keimanan (QS.49.17). KeIslaman seseorang adalah nikmat dari Allah, bukan balas jasa kepada Allah.

\section{2). Hidayah kepada penggunaan akal pikiran dan analisis}

Allah telah menganugrahkan kepada manusia potensi akal atau kecerdasan. Dengan akal yang dimiliki manusia dapat dijadikan alat membedakan yang baik dan buruk, yang halal dengan haram. Demikian pula Allah memberikan kemampuan kepada manusia untuk melakukan analisis dan penyelidikan. Pendidikan mengarah kemampuan akal dan analisis untuk mendekatkan diri kepada Allah. Jalan yang baik dan buruk ditunjukkan Allah kepada manusia untuk memilihnya (QS.90:10 dan QS.76:3).

\section{3). Hidayah kepada akhlak mulia}

Pendidkan Islam dalam semua aspeknya bermuara kepada terbentuknya akhlak yang mulia. Sebagai pendidik,akhlak adalah alat yang dijadikan mengarahkan anak. Sikap lemah lembut,tegas,jujur,dan adil menjadi alat perilaku anak. Sifat mulia ini harus ada dalam perilaku pendidk (QS.3:159)

\section{4). Hidayah ke arah perbuatan shaleh}

Dalam fitrah manusia ada kecendrungan pada keinginan memelihara diri, kerjasama dan bergaul dengan orang lain untuk kepentinagan bersama. Setiap pribadi wajid dipersiapkan memasuki sitem sosial yang

\section{B. Globalisasi dan Dampaknya dalam Dunia Pendidikan.}

Banyak sekolah di Indonesia dalam beberapa tahun belakangan ini mulai melakukan globalisasi dalam sistem pendidikan internal sekolah. Hal ini terlihat pada sekolah-sekolah yang dikenal dengan billingual school, dengan diterapkannya bahasa asing seperti bahasa Inggris dan bahasa Mandarin sebagai mata ajar wajib sekolah. Selain itu berbagai jenjang

22 Fadhil Al-Djamali, Menerebas Krisis Pendidikan Dunia Islam, (Jakarta: PT. Golden Terayon Press, 1993) h. 58-59 


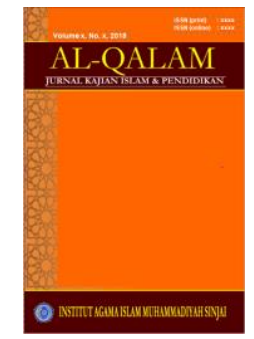

AL-QALAM

Jurnal Kajian Islam \& Pendidikan

Volume 7, No. 1, 2015

ISSN (print) : 1858-4152

ISSN (online) : 2715-5684

Homepage : http://journal.al-qalam.iaims.ac.id

pendidikan mulai dari sekolah dasar hingga perguruan tinggi baik negeri maupun swasta yang membuka program kelas internasional. Globalisasi pendidikan dilakukan untuk menjawab kebutuhan pasar akan tenaga kerja berkualitas yang semakin ketat. Dengan globalisasi pendidikan diharapkan tenaga kerja Indonesia dapat bersaing di pasar dunia. Apalagi dengan akan diterapkannya perdagangan bebas, misalnya dalam lingkup negara-negara ASEAN, mau tidak mau dunia pendidikan di Indonesia harus menghasilkan lulusan yang siap kerja agar tidak menjadi "budak" di negeri sendiri. Pendidikan model ini juga membuat siswa memperoleh keterampilan teknis yang komplit dan detil, mulai dari bahasa asing, komputer, internet sampai tata pergaulan dengan orang asing dan lain-lain. sisi positif lain dari liberalisasi pendidikan yaitu adanya kompetisi. Sekolah-sekolah saling berkompetisi meningkatkan kualitas pendidikannya untuk mencari peserta didik.

Globalisasi seperti gelombang yang akan menerjang, tidak ada kompromi, kalau tidak siap maka akan diterjang, kalau tidak mampu maka akan menjadi orang tak berguna dan hanya akan menjadi penonton saja. Akibatnya banyak Desakan dari orang tua yang menuntut sekolah menyelenggarakan pendidikan bertaraf internasional dan desakan dari siswa untuk bisa ikut ujian sertifikasi internasional. Sehingga sekolah yang masih konvensional banyak ditinggalkan siswa dan pada akhirnya banyak pula yang gulung tikar alias tutup karena tidak mendapatkan siswa. Implikasinya, muncullah :

a. Home schooling, yang melayani siswa memenuhi harapan siswa dan orang tua karena tuntutan global

b. Virtual School dan Virtual University Munculnya alternatif lain dalam memilih pendidikan

c. Model Cross Border Supply, yaitu pembelajaran jarak jauh

d. Model Consumption Aboard, lembaga pendidikan suatu negara menjual jasa pendidikan dengan menghadirkan konsumen dari negara lain;

e. Model Movement of Natural Persons.

f. Model Commercial Presence, yaitu penjualan jasa pendidikan oleh lembaga di suatu negara bagi konsumen yang berada di negara lain dengan mewajibkan kehadiran secara fisik lembaga penjual jasa dari negara tersebut.

Persaingan untuk menciptakan negara yang kuat terutama di bidang ekonomi, sehingga dapat masuk dalam jajaran raksasa ekonomi dunia tentu saja sangat membutuhkan kombinasi antara kemampuan otak yang mumpuni disertai dengan keterampilan daya cipta yang tinggi. Salah satu kuncinya adalah globalisasi pendidikan yang dipadukan dengan kekayaan budaya bangsa Indonesia. Selain itu hendaknya peningkatan kualitas pendidikan hendaknya selaras dengan kondisi masyarakat Indonesia saat ini.

Tidak dapat dipungkiri bahwa masih banyak masyarakat Indonesia yang berada di bawah garis kemiskinan, untuk dapat menikmati pendidikan dengan kualitas yang baik, tentunya memerlukan biaya yang cukup besar. Hal ini menjadi salah satu penyebab globalisasi pendidikan belum dirasakan oleh semua kalangan masyarakat. Sebagai contoh untuk dapat menikmati program kelas Internasional di perguruan tinggi terkemuka di tanah air diperlukan dana yang lebih besar. Alhasil hal tersebut hanya dapat dinikmati golongan kelas atas yang mapan. 


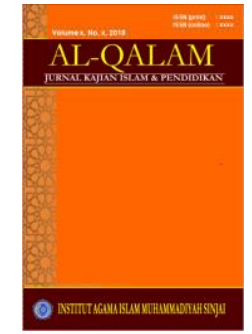

AL-QALAM

Jurnal Kajian Islam \& Pendidikan

Volume 7, No. 1, 2015

ISSN (print) : 1858-4152

ISSN (online) : 2715-5684

Homepage : http://journal.al-qalam.iaims.ac.id

Dengan kata lain yang maju semakin maju, dan golongan yang terpinggirkan akan semakin terpinggirkan dan tenggelam dalam arus globalisasi yang semakin kencang yang dapat menyeret mereka dalam jurang kemiskinan. Masyarakat kelas atas menyekolahkan anaknya di sekolah mewah di saat masyarakat golongan ekonomi lemah harus bersusah payah bahkan untuk sekedar menyekolahkan anak mereka di sekolah biasa. Ketimpangan ini dapat memicu kecemburuan yang berpotensi menjadi konflik sosial. Peningkatan kualitas pendidikan yang sudah tercapai akan sia-sia jika gejolak sosial dalam masyarakat akibat ketimpangan karena kemiskinan dan ketidakadilan tidak diredam.

Selain itu ketidaksiapan sekolah dalam menyelenggarakan pendidikan bertaraf internasional dan ketidaksiapan guru yang berkompeten dalam menyelenggarakan pendidikan tersebut merupakan perpaduan yang klop untuk menghasilkan lulusan yang tidak siap pula berkompetisi di era globalisasi ini alias lulusan yang kurang berkualitas.

Pendidikan di Indonesia sekarang membuat rakyat biasa sangat menderita. Pendidikan menjadi sesuatu yang tak terjangkau rakyat kecil. Tidak ada penggolongan orang miskin dan orang kaya. Lembaga pendidikan telah dijadikan ladang bisnis dan dikomersialkan.

Kebijakan yang mahal ini memang sangat merisaukan karena akan mengubur impian mobilitas kelas sosial bawah untuk memperbaiki status kelasnya. Melalui sistem ini, maka yang bisa diserap dalam lingkungan pendidikan adalah mereka yang memiliki modal yang cukup. Sekolah kian menjadi lembaga elite dan bahkan menjadi kekuatan yang menghadang arus mobilitas vertikal kelas sosial bawah. Dalam beberapa aktivitasnya bahkan sekolah ikut terlibat melegitimasi tatanan yang timpang. Jika diusut penyebab ini semua, tentu jawabannya adalah kebijakan ekonomi neoliberal. Neoliberalisme berangkat dari keyakinan akan kekuatan pasar serta pelumpuhan kekuasaan negara. Sekolah tidak perlu menjadi tanggungan negara, cukup diberikan pada mekanisme pasar. Biarlah pasar yang akan menyeleksi mana sekolah yang patut dipertahankan dan mana yang harus gulung tikar. Pendidikan berangsur-angsur menjadi tempat eksklusif yang memberi pelayanan hanya pada mereka yang kuat membayar.

Implikasinya, jutaan rakyat Indonesia belum memperoleh pendidikan yang layak. Bahkan tidak sedikit pula yang masih berkategori masyarakat buta huruf. Mereka belum bisa menikmati dunia pendidikan seperti anggota masyarakat yang mampu "membeli" dan menikmati pendidikan. Masyarakat demikian mencerminkan suatu kesenjangan yang serius karena di satu sisi ada sebagian yang bisa membeli politik komoditi pendidikan secara mahal. Sementara tidak sedikit anggota masyarakat yang tidak cukup punya kemampuan ekonomi untuk bisa membebaskan diri dari buta huruf akibat dunia pendidikan yang tidak berpihak secara manusiawi kepada dirinya. Biaya pendidikan yang melangit ini terjadi di dunia pendidikan dasar, menengah hingga pendidikan tinggi.

Tidak hanya itu implikasi dari makin mahalnya biaya pendidikan. Kualitas mahasiswa yang masuk perguruan tinggi pun nantinya patut dipertanyakan karena bukan tidak mungkin uang yang akan berbicara. Siapa yang lebih banyak bayarnya dia yang akan menang. Bisa jadi mereka yang memiliki kemampuan intelektual pas-pasan bisa mengenyam pendidikan di jurusan dan universitas favorit karena dia bisa membayar biaya yang cukup tinggi. Sementara 


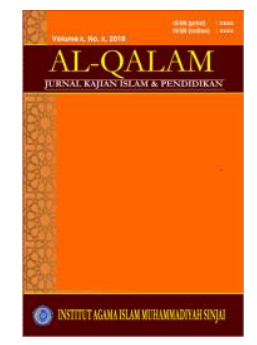

\section{AL-QALAM}

Jurnal Kajian Islam \& Pendidilkan

Volume 7, No. 1, 2015

ISSN (print) : 1858-4152

ISSN (online) : 2715-5684

Homepage : http://journal.al-qalam.iaims.ac.id

itu, mereka yang memiliki kemampuan lebih tidak bisa menyandang gelar mahasiswa lantaran tidak memiliki kemampuan finansial.

Realitas menunjukkan, krisis yang menimpa dunia pendidikan di Indonesia, khususnya kualitas pendidikan yang rendah, merupakan persoalan yang sangat kompleks. Prasarana, sarana, dan fasilitas kurang memadai, anggaran pendidikan nasional yang sangat minim, dan banyaknya guru yang mengajar tidak sesuai dengan keahlian atau memang belum layak disebut guru merupakan faktor yang ikut menyulitkan pengembangan kualitas pendidikan.

Selain itu telah muncul banyak pernyataan dan keluhan tentang rendahnya kualitas sumber daya manusia Indonesia, yang tentu saja terkait dengan mutu lulusan yang dihasilkan oleh sistem pendidikan. Padahal, anggaran negara yang dialokasikan untuk pendidikan itu selalu bertambah dari tahun ke tahun. Sungguh ironis memang, anggaran selalu naik tetapi kualitas lulusan tetap rendah dan justru dirasakan semakin mahal. Mengapa hal seperti ini terjadi, padahal kurikulum dan buku, entah sudah berapa kali diubah. Entah sudah berapa macam metode mengajar yang ditatarkan kepada guru. keadaan ini tidak bisa dibiarkan terus berlanjut, pendidikan tidak dapat disebut sebagai investasi untuk masa depan, jika tidak menghasilkan lulusan yang berkualitas dan diandalkan.

Namun seringkali masyarakat hanya dibuai oleh janji-janji anggaran atau kebijakan bertemakan "alokasi". Faktanya mimpi masyarakat ini sulit terkabul dengan alasan-alasan yang politis. Pejabat belum sungguh-sungguh menempatkan dunia pendidikan ini sebagai penyangga kemajuan bangsa. Kenyataannya memang demikian. Subsidi pemerintah pemerintah perlahan menyurut hingga tak lagi dapat mencukupi kebutuhan universitas. Namun di balik itu semua ada hal yang terlewatkan oleh para pimpinan universitas yang semakin mahalnya biaya pendidikan. Yakni, kaum miskin hanya bisa gigit jari karena tidak dapat meneruskan ke jenjang pendidikan tinggi.

Selain itu banyak penyelewengan-penyelewengan anggaran pendidikan yang dilakukan oleh dilakukan aparat dinas pendidikan di daerah dan sekolah. Peluang penyelewengan dana pendidikan itu terutama dalam alokasi dana rehabilitasi dan pengadaan sarana prasarana sekolah serta dana operasional sekolah.

Padahal tujuan utama dari pengucuran dana pendidikan tersebut seperti dana BOS adalah untuk meningkatkan mutu pendidikan, menaikkan kualitas tenaga pendidik supaya siswa Indonesia memiliki daya saing di tingkat internasional.

\section{Pendidikan Islam dalam Menghadapi Era Globalisasi Sebuah Keniscayaan}

Efek negative dari globalisasi harus dihadapi oleh agama yang mendidik ke arah perdamaian, keadilan, dan kesejahteraan hidup. ${ }^{23}$

Difahami bahwa persoalan internal pendidikan Islam sendiri, baik secara kelembagaan maupun keilmuan. Masih menghadapi persoalan-persoalan yang belum terpecahkan, dari persoalan manajemen, ketenagaan, sumber dana, infrastruktur dan kurikulum. Akibatnya mutu pendidikan Islam sangat rendah juga dibarengi oleh para pengelola pendidikan Islam

23 Abdurrahman Assegap, Pendidikan Tanpa Kekerasan: Tipologi Kondisi, Kasus dan Konsep (Yogyakarta: Tiara Wacana, 2004, h. 150. 


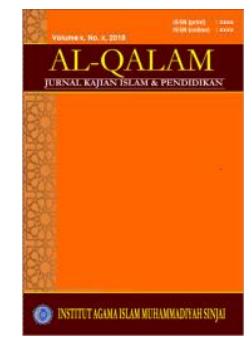

AL-QALAM

Jurnal Kajian Islam \& Pendidikan

Volume 7, No. 1, 2015

ISSN (print) : 1858-4152

ISSN (online) : 2715-5684

Homepage : http://journal.al-qalam.iaims.ac.id

tidak lagi sempat dan mampu mengantisipasi adanya tantangan globalisasi yang menghadang di depan.

Efek negatif yang menyertai munculnya globalisasi yang harus dihadapi oleh pendidikan Islam, itu antaranya persaingan bisnis yang sangat ketat, nilai-nilai agama sudah bergeser dan kabur, dekadensi moral, pergaulan remaja yang cenderung bebas, kebutuhan hidup yang tinggi sehingga sering merusak kelembagaan keluarga, penyalahgunaan obatobatan, minum-minuman keras, dan penyakit sosial lainnya.

Menghadapi problem yang demikian berat, pendidikan Islam tidak bisa menghadapinya dengan model-model pendidikan dan pembelajaran seperti yang sudah ada sekarang ini. Pendidikan Islam harus terus menerus melakukan pembenahan dan inovasi serta bekerja keras untuk memperbaiki kelemahan-kelemahan yang ada dan juga melakukan langkah-langkah baru ke arah kemajuan khususnya Sumber Daya Manusia. ${ }^{24}$

Dari pengembangan keilmuan, dari berbagai problem yang muncul di atas, jelas tidak bisa direspon hanya dengan ilmu-ilmu yang selama ini di lembaga pendidikan Islam seperti fiqih, kalam, tasawuf, aqidah akhlak, tarikh. ${ }^{25}$

Ilmu-ilmu tersebut di atas tidak mampu menjawab persoalan aktual pada lingkungan hidup seperti: global warming, datangnya industri, adanya pencemaran limbah beracun, penggundulan hutan, gedung pencakar langit, polusi udara, dan problem sosial antara lain banyaknya pengangguran, penegakan hukum, hak asasi manusia dan sebagainya.

Dalam hal ini ilmu keislaman perlu dan butuh dukungan ilmu lain seperti ilmu-ilmu sosial, humaniora, kealaman secara interkoneksi dan saling mendukung.

Arus global itu bukan lawan atau kawan bagi pendidikan Islam, melainkan sebagai dinamisator. Bila pendidikan Islam mengambil posisi anti global, maka akan stagnan tidak bergerak dan pendidikan Islam akan mengelami penutupan intelektual. Sebaliknya bila pendidikan Islam terseret oleh arus global, tanpa daya identitas keislaman sebagai sebuah proses pendidikan akan dilindas. Oleh karena itu, pendidikan Islam harus memposisikan diri dengan menakar arus global, dalam arti yang sesuai dengan nilai-nilai ajaran Islam untuk diadopsi dan dikembangkan. Sedangkan yang tidak sesuai dengan nilai-nilai ajaran Islam diulurkan, dilepas dan ditinggalkan. Bilamana pendidikan Islam itu menutup diri (bersikap eksklusif) akan ketinggalan zaman, sedangakan jika membuka diri beresiko kehilangan jati diri atau kepribadian. ${ }^{26}$

Bagi pendidikan Islam, turbulensi ${ }^{27}$ arus global bisa menimbulkan paradoks atau gejala kontra moralitas, yakni pertentangan dua fisi moral secara diametral, contoh guru

${ }^{24}$ H. A. Malik Fadjar (ed), Platform Reformasi Pendidikan dan Pengembangan Sumber Daya Manusia. (Jakarta: Logos Wacana Ilmu, 1999), h. 10.

${ }^{25}$ T. Raka Joni, Memicu Perbaikan Melalui Kurikulum Dalam Kerangka Pikir Desentralisasi dalam Sindunata (ed), Membuka Masa Depan Anak-Anak Kita. (Yogyakarta: Kanisius, 2000) h. 253. Lihat juga: Donald Arstine, Philosophy of Education. (New York: Harper and Row, 1976). h. 339

${ }^{26}$ Mastuhu, Memberdayakan Sistem Pendidikan Islam, (Jakarta: Logos, 2003), h. 126

27 Turbulence dapat dimaknai violence, disorderly dan uncontrolled (AS Hornby, 1986: 929) atau pergolakan, kerusuhan, dan kekacauaan (John M. Echols, 1987: 607). Pada awalnya keadaan turbulensi ini dipakai untuk menjelaskan karekter mesin turbo yang meggerakkan propeler pesawat dengan putarannya, sehingga pesawat tersebut dapat terbang kemudian digunakan di bidang sosial untuk menjelaskan kondisi 


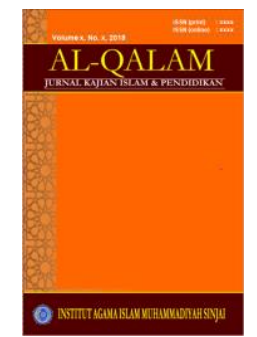

\section{AL-QALAM}

Jurnal Kajian Islam \& Pendidikan

Volume 7, No. 1, 2015

ISSN (print) : 1858-4152

ISSN (online) : 2715-5684

Homepage : http://journal.al-qalam.iaims.ac.id

menekankan dan mendidik para siswanya berdisiplin berlalu lintas tetapi realita di lapangan sopir bus tidak berlalu lintas, guru mengajar anak didiknya untuk tidak dan menghindar tawuran antar pelajar akan tetapi siswa melihat dilayar televise anggota DPR RI tidak bisa mengendalikan emosinya di mata bangsa, di sekolah diadakan razia pornografi di media Televisi, internet menampilkan pornografi termasuk iklan-iklan yang merangsang hawa nafsu syahwat, dan lain-lain. ${ }^{28}$

Karena globalisasi, langsung atau tidak, dapat membawa paradoks bagi praktik pendidikan Islam, seperti terjadinya kontra moralitas antara apa yang diidealkan dalam pendidikan Islam dengan realitas di lapangan berbeda, maka gerakan tajdid dalam pendidikan Islam hendaknya melihat kenyataan kehidupan masyarakat lebih dahulu, sehingga ajaran Islam yang hendak dididikkan dapat landing, dan sesuai dengan kondisi masyarakat setempat agar dapat dirasakan makna dan faedahnya, akan tetapi mengabaikan lingkungannya tentu akan kehilangan makna ibadah itu sendiri.

Pendidikan Islam dalam tataran idealisme mengalami benturan nilai dengan peristiwa yang terjadi di berbagai belahan dunia, di mana dalam era global ini bisa langsung dilihat di layar TV perang antar Negara, kerusuhan massal, unjuk rasa yang anarkis, pemberontakan gerakan sparatis, dan lain-lain. Pendidikan Islam mengajarkan aurat kaum hawa apabila menginjak dewasa atau baligh, akan tetapi arus global non- islami menciptakan sebaliknya yakni buka paha tinggi dan buka wilayah dada, sebagaimana yang ditayangkan di televisi dan internet, berupa pornografi dan pornoaksi, adalah trends modernitas. ${ }^{29}$

Perlu diketahui bersama bahwa hadirnya media massa terutama TV memberikan dampak tertentu kepada masyarakat kalangan remaja yang kadang kala menimbulkan efek dehumanisasi, demoralisasi.

Tiga hal yang merupakan tema sentral hadirnya turbulensi arus global bagi pendidikan Islam dewasa ini adalah: Lifestyle, gaya makanan, gaya hiburan, dan gaya berpakaian (food, fun, and fashion).

Jika pendidikan Islam tidak berbuat apa-apa dalam menghadapi perkembangan teknologi canggih dan modern tersebut, dapat dipastikan bahwa umat Islam akan pasif sebagai penonton bukan pemain, sebagai konsumen bukan produsen.

\section{Memformulasikan Pendidikan Islam dalam Era Global Dan Pemecahannya}

Upaya memformulasikan kembali teori dan praktek pendidikan Islam segera dilakukan. Untuk itu pendidikan Islam harus kontekstual terhadap arus global, pada intinya menghilangkan batas pendidikan Islam yang dikotomik menuju pendidikan yang integralistik.

Hal-hal yang perlu dilakukan pendidikan Islam antara lain:

a. Mengharmoniskan kembali ayat-ayat ilahiyah dengan ayat-ayat kauniyah

masyarakat yang sedang bergejolak, rusuh atau kacau (Lihat Islam dan Turbulensi, Mustopa Imam Mahat, Jogjakarta: Arru Media, h. 10)

${ }^{28}$ Sudarman Danim, Agenda Pembaharuan Sistem Pendidikan. (Yogyakarta: Pustaka Pelajar, 2003), h. 64

${ }^{29}$ Sudarman Danim, Agenda Pembeharuan...h. 107-109 


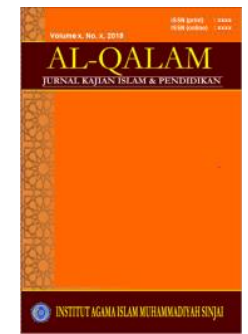

AL-QALAM

Jurnal Kajian Islam \& Pendidikan

Volume 7, No. 1, 2015

ISSN (print) : 1858-4152

ISSN (online) : 2715-5684

Homepage : http://journal.al-qalam.iaims.ac.id

b. Islamisasi ilmu pengetahuan.

c. Mengharmoniskan kembali relasi Tuhan-manusia dalam bentuk pendidikan yang teoantropo-sentris dengan titik tekan bahwa manusia itu makhluk Tuhan yang mulia.

d. Mengharmoniskan antara iman dengan ilmu keduanya tidak boleh dipisahkan.

e. Mengharmoniskan antara pemenuhan kebutuhan rohani (spiritual-ukhrawi) dengan pemenuhan kebutuhan jasmani (material-duniawi)

f. Mengharmoniskan antara wahyu dengan daya intelek (berfikir, kritis dan rasional)

\section{PENUTUP}

Pendidikan adalah suatu proses yang mempunyai tujuan yang biasanya diusahakan untuk menciptakan pola-pola tingkah laku tertentu pada kanak-kanak atau orang yang sedang dididik. Setiap suasana pendidikan mengandung tujuan-tujuan, maklumat-maklumat berkenaan dengan pengalaman-penglaman yang dinyatakan sebagai materi, dan metode yang sesuai untuk mempersembahkan materi itu secara berkesan kepada anak.

Globalisasi pendidikan membawa dampak adanya kesenjangan sosial di dalam dunia pendidikan, karena hanya orang-orang yang mempunyai modal lebih besar saja yang dapat menikmati kualitas pendidikan dengan standar internasional, merosotnya kualitas pendidikan, Perlu adanya perombakan pada kebijakan yang menyangkut masalah pendidikan dengan menelurkan kebijakan-kebijakan yang berpihak pada kaum miskin, komersialisasi pendidikan mutlak harus dihentikan karena hanya memunculkan sekelompok orang yang menggunakan pendidikan sebagai alat untuk mendapatkan keuntungan.

Upaya memformulasikan kembali teori dan praktek pendidikan Islam sehingga kontekstual terhadap arus global dengan menghilangkan batas pendidikan Islam yang dikotomik menuju pendidikan yang integralistik.

Penulis berharap kepada seluruh yang memiliki komitmen terhadap pengembangan ilmu utamanya ilmu pendidikan Islam kiranya dapat memberikan sumbang saran dan kritikan yang bersifat ilmiah guna melengkapi makalah yang penulis yakin masih sangat jauh dari kesempurnaan. 


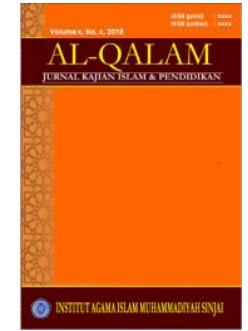

AL-QALAM

Jurnal Kajian Islam \& Pendidikan

Volume 7, No. 1, 2015

ISSN (print) : 1858-4152

ISSN (online) : 2715-5684

Homepage : http://journal.al-qalam.iaims.ac.id

\section{DAFTAR PUSTAKA}

Al-Qur'an

Alam, Zafar, Islamic Education Theory \& Practive. New Delhi: Adam Publishers \& Distributors, 2003.

Ashraf, Syed Ali, New Horizon in Muslim Education. Jakarta: Pustaka Mantiq, 1989.

Assegap, Abdurrahman, Pendidikan Tanpa Kekerasan: Tipologi Kondisi, Kasus dan Konsep. Yogyakarta: Tiara Wacana, 2004.

Attas, Syed Naquib, Aims and Objective of Islamic Edication. Jeddah: Hodder and Stoughton King Abdul Aziz University, 1979.

Al-Baqi, Muhammad Fu'ad, Mu'jam Al-Mufahras li-Al Fazh Al-Qur'an Al-Karim. Indonesia: Maktabah Dahlan, tt.

Danim Sudarman, Agenda Pembaharuan Sistem Pendidikan. Yogyakarta: Pustaka Pelajar, 2003.

Al-Djamali, Fadhil, Menerebas Krisis Pendidikan Dunia Islam. Jakarta: PT. Golden Terayon Press, 1993.

Fadhil Al-Djamali, Menerebas Krisis Pendidikan Dunia Islam, Jakarta: PT. Golden Terayon Press, 1993.

Fadjar, H. A. Malik (ed), Platform Reformasi Pendidikan dan Pengembangan Sumber Daya Manusia. Jakarta: Logos Wacana Ilmu, 1999.

Husaini, S.Wakar Ahmed, Sistem Pembinaan Masyarakat Islam, Bandung: Pustaka, 1983.

Langgulung, Hasan, Manusia dan Pendidikan; Suatu Analisa Psikologi, Filsafat dan Pendidikan. Jakarta: Pustaka Al-Husna, 1989.

Mahat, Mustopa Imam, Islam dan Turbulensi. Jogjakarta: Arru Media, tt.

Mastuhu, Memberdayakan Sistem Pendidikan Islam. Jakarta: Logos, 2003.

T. Raka Joni, Memicu Perbaikan Melalui Kurikulum Dalam Kerangka Pikir Desentralisasi dalam Sindunata (ed), Membuka Masa Depan Anak-Anak Kita. Yogyakarta: Kanisius, 2000. 